Short Communication

\title{
Study of a Fuel Electrode-Supported Solid Oxide Electrolysis Cell Prepared by Aqueous Co-Tape Casting
}

\author{
Chao Liu', Lan Zhang ${ }^{2}$, Yifeng Zheng ${ }^{3}$, Jiangge Pu ${ }^{1}$, Juan Zhou ${ }^{1,4, *}$, Siew Hwa Chan ${ }^{2, *}$ \\ ${ }^{1}$ School of Energy and Power Engineering, Nanjing University of Science and Technology, 200 \\ Xiaolingwei Street, Jiangsu Province, 210094, China \\ ${ }^{2}$ School of Mechanical and Aerospace Engineering, Nanyang Technological University, 50 Nanyang \\ Avenue, Singapore 639798, Singapore \\ ${ }^{3}$ College of Materials Science and Engineering, Nanjing Tech University, No.5 Xinmofan Road, \\ Jiangsu Province, 210009, China \\ ${ }^{4}$ Jiangsu Province Engineering Laboratory of High Efficient Energy Storage Technology and \\ Equipments, China University of Mining and Technology, Xuzhou 221116, China \\ *E-mail: jzhou@njust.edu.cn (Juan Zhou), mshchan@ntu.edu.sg (Siew Hwa Chan).
}

doi: $10.20964 / 2019.12 .37$

Received: 5 July 2019 / Accepted: 13 September 2019 / Published: 29 October 2019

High temperature solid oxide electrolysis cells (SOECs) have the potential to efficiently and economically produce of hydrogen fuels. In this paper, large area fuel electrode-supported half cells with $\mathrm{Zr}_{0.92} \mathrm{Y}_{0.08} \mathrm{O}_{2-\delta}$ (YSZ) electrolyte and Ni/YSZ fuel electrode were fabricated by aqueous-based co-tape casting in conjunction with co-sintering, and the air electrode with $\mathrm{La} 0.6 \mathrm{Sr}_{0.4} \mathrm{Co}_{0.2} \mathrm{Fe}_{0.8} \mathrm{O}_{3+\delta} / \mathrm{Ce}_{0.9} \mathrm{Gd}_{0.1} \mathrm{O}_{2+\delta}$ (LSCF/CGO) was fabricated by screen printing. In solid oxide fuel cell (SOFC) mode, the maximum power density is $447 \mathrm{~mW} \mathrm{~cm}^{-2}$ at $800{ }^{\circ} \mathrm{C}$ with humidified $\mathrm{H}_{2}$ as the fuel and air as the oxidant. In solid oxide electrolysis cell (SOEC) mode, the hydrogen production rate of button cell is $222.2 \mathrm{ml} \mathrm{h}^{-1} \mathrm{~cm}^{-2}$ under an electrolysis voltage of $1.3 \mathrm{~V}$ with $70 \mathrm{vol} . \%$ steam.

Keywords: Aqueous Tape Casting; Fuel Electrode-Supported; Solid Oxide Electrolysis Cells (SOECs)

\section{FULL TEXT}

(C) 2019 The Authors. Published by ESG (www.electrochemsci.org). This article is an open access article distributed under the terms and conditions of the Creative Commons Attribution license (http://creativecommons.org/licenses/by/4.0/). 